\title{
Impact of Personality Traits on Entrepreneurial Intentions of University Students
}

\author{
Ishfaq Ahmed \\ Muhammad Ramzan \\ Muhammad Usman
}

\begin{abstract}
In the hard times when educated persons can not get a job, self employment is referred as the solution. But entrepreneurship is not the function that might be outcome of simple efforts. It requires a regular and permanent attitude as part of personality. This research aims to study the impact of personal traits on entrepreneurial intentions of university students. Two individual personality traits were taken as predictor of entrepreneurial intentions, locus of control and self efficacy. Data was collected from the sample size of 276 university students. All of the students were in the final semesters of their studies. Results show strong relation between personal traits and entrepreneurial intentions. However some demographic characteristics like gender were insignificant with the intentions to become entrepreneurs, but prior experience, family exposure to business and entrepreneurial education have significant relation with intentions to become an entrepreneur.
\end{abstract}

Keywords: Entrepreneurship, locus of control, self-efficacy, entrepreneurial intentions.

\section{Introduction}

\subsection{Background of the Study}

For decades, unemployment rate has been mounting. Recent world financial crisis has also resulted in unemployment at vast level. In Pakistan, terrorism and the resulting law and order situation has shattered all kinds of economic activities. It has created unemployment at very large scale in Pakistan. To employee these unemployed persons is a big challenge for authorities. One of the most effective alternates suggested by the economists is self employment. Self employment or entrepreneurship contributes a great amount of output through out the world and our country is no exception.

It is well said that a career in entrepreneurship offers individuals with significant opportunities to achieve independence, reap greater financial payback and gain benefits by contributing to innovation, job creation, and economic development. For developing economies, entrepreneurship works like an engine for economic growth, job creation and social adjustment. There is also positive relationship between entrepreneurship intentions and personality traits (Yosuf et al. 2007). Gartner (1988) says that the entrepreneurs are individuals with distinctive and specific personality traits. Personality traits have direct impact on many entrepreneurial activities including the intention to launch a new business, success in business and to enhance entrepreneurial set up (Shaver and Scott, 1991).

\subsection{Study objective}

This study is aimed at conducting a research survey of students to identify their entrepreneurial intentions on the basis of their personality traits identified by literature. Secondly, to assess which traits lead individuals' intentions towards self-employment and entrepreneurship.

\subsection{Significance of the Study}

Unemployment rate is increasing in our country. One solution suggested by researchers is self-employment and entrepreneurship. This study would be an addition to existing literature and more significantly it will be more helpful in Pakistani scenario as not much literature is available with respect to Pakistan.

\section{$1.4 \quad$ Research Methodology}

A cross sectional study design was conducted among the students of final semester of graduate courses. Sample size of the study was 300. Out of this sample, $276(92 \%)$ responded back. The study aimed to explore whether students who are going to pass out have more inclination towards entrepreneurial intentions. 
A questionnaire was adopted from the research of Plattner et al. (2009). Elements of locus of control and self efficacy were taken from Plattner et al. (2009) work. Most variables were operationalized through statements and pre-given answer categories (e.g., 'true', 'not sure', 'false'). Entrepreneurial intention was explored through the fiver point scale ranging from 1 for "most unlikely" to 5 for "most likely", the question used was "Would you like to start your own business? Plattner et al. (2009) used two questions titled as "Knowing me, I will definitely find a job when I complete my studies" and "If I work hard and get good grades I will get a job when I complete my studies", to assess self-efficacy of students. The variable locus of control was assessed through three questions "Connections with the right people will help me to find a job when I complete my studies", "I need to be lucky to get a job when I complete my studies" and "The government has to provide me with a job when I complete my studies".

Demographics were taken containing five elements; age, gender, entrepreneurial experience, entrepreneurial parents, and entrepreneurial course if gone through. Age was divided in two groups, below 25 and above 25 years. Entrepreneurial experience, entrepreneurial parents and entrepreneurial courses profile were collected through questions using alternate response (Yes or No). Impact of locus of control and self efficacy on entrepreneurial intentions was assessed through the Regression Analysis. SPSS 16 was used for this purpose.

\subsubsection{Variables}

This study includes four variables. Predictor variables, locus of control and self efficacy were taken from the research of Plattner et al. (2009). Additionally, demographic was the third predictor variable. Impact of these predictors was measured on entrepreneurial intentions.

1. Locus of Control

2. Self-efficacy

3. Entrepreneurial Intentions

4. Demographic Factors

\section{Locus of Control}

Locus of control means individuals perception regarding reward and punishment in his life (Pervin, 1980). It can be referred to level of control one have over the happenings of his life (Rotter, 1966). Individuals with internal locus of control have firm belief that they control happenings of their own life, while individuals with an external locus of control refer happenings to external factors, such as fate, chance or luck. Empirically, it is proved that internal locus of control is one of the major traits of entrepreneurs and can be a big determinant of success of enterprise (Ho and Koh, 1992; Robinson et al., 1991; Koh, 1996; Cromie, 2000). Locus of control refers to perception that one can personally affect particular outcomes relevant to him or her. Internals (people with internal locus of control) believe results are the outcomes of their own efforts, will and abilities. On the other hand, individuals with external locus of control believe that outcomes are beyond their control and external factors like circumstances, luck, fate, knowing right people etc. is the main reason of the results (McGee et al. 2009). Bonnett and Furnham (1991) found that internal locus of control was positively associated with the desire to become an entrepreneur.

\section{Self-Efficacy}

Self efficacy bears positive impact on intentions to become entrepreneur (Chen et al. 1998). Self efficacy is one's self cognitive estimate towards his or her capabilities to utilize motivation, available cognitive resources, and courses of action needed to overcome the events in his or her life (Wood \& Bandura, 1989). Boyd and Vozikis (1994) propose that entrepreneurial choice and development are affected by the self efficacy of individuals. Self efficacy is also important predictor of determining the strength of entrepreneurial intentions and putting them in real term actions. McGee et al. (2009) also found that there is a positive relationship between self efficacy and entrepreneurial intentions.

\section{Demographic Factors}

Demographic factors that affect entrepreneurial activities are age, sex, education, work experience (Ismail et al. 2009). Mazzarol et al. (1999) found that females are less entrepreneurial spirit when compared to male. Kolvereid (1996) states that previous experience also determines entrepreneurial behaviors of individuals, those with prior experience are more likely to incline towards entrepreneurship. Prior exposure could be in the form of early exposure to a family business, or self experience which influences the entrepreneurial attitudes (Krueger 1993; Carr \& Sequeira 2006).

\section{Entrepreneurial Intentions}


Empirical studies generally support the existence of relationship between personality traits of individuals and their intentions to become entrepreneur (McGee 2009, Kolvereid 1996; Kreuger et al. 1993).

\section{Data Analysis and Findings}

The effects of demographic characteristics on entrepreneurial intentions were analyzed through regression analysis. Table 1, shows that gender is not having significant effect on entrepreneurial intentions. Previous personal experience and family experience towards entrepreneurship is having significant effect on the entrepreneurial intentions. Finally, entrepreneurial educational background is also having impact on the entrepreneurial intentions of students, but it is not as significant as entrepreneurial intentions and entrepreneurial parents and family background.

Table-1

\section{Demographic factors and Entrepreneurial Intentions}

\begin{tabular}{|l|l|c|c|c|}
\hline \multicolumn{2}{|c|}{ Variable } & N & Mean & p-value \\
\hline \multirow{2}{*}{ Gender } & Male & 120 & 3.15 & \multirow{2}{*}{0.40} \\
\cline { 2 - 4 } & Female & 156 & 3.03 & \\
\hline \multirow{2}{*}{ Entrepreneurial Experience } & Yes & 35 & 3.8 & \multirow{2}{*}{0.01} \\
\cline { 2 - 4 } & No & 241 & 2.38 & \\
\hline \multirow{2}{*}{ Entrepreneurial Parents } & Yes & 54 & 3.79 & \multirow{2}{*}{0.01} \\
\cline { 2 - 4 } & No & 222 & 3.12 & \\
\hline \multirow{2}{*}{$\begin{array}{l}\text { Taken Entrepreneurial } \\
\text { Course }\end{array}$} & yes & 194 & 3.68 & \multirow{2}{*}{0.02} \\
\cline { 2 - 4 } & No & 82 & 3.01 & \\
\hline
\end{tabular}

Out of 276 respondents, 163 were male students and 114 were female students. The average age of students was 20.78 years. Out of the sample, $53 \%$ were brought up in rural areas. $48.8 \%$ of the respondents were enrolled in faculties of commerce and management sciences, $22 \%$ were enrolled in faculty of social sciences, $10.2 \%$ were students of faculty of education, $8 \%$ were from faculty of sciences and $11 \%$ were faculty of humanity.

Table 2 shows that only $57 \%$ of the respondents reported to be agreed with the statement that "they would get job after completing their studies" shows strong relation between self efficacy and entrepreneurial setup and intentions ( $p$ 0.01). Similarly, second element of self-efficacy "belief in hard work" was highly significant (p 0.009) and shows strong relation between self efficacy and entrepreneurial intentions.

In contrast, $40 \%$ of the students believe that "connections" with the "right" people would help them find a job, this shows poor level of internal locus of control of students and same is proved by the p value (0.068) which is highly insignificant. Regarding luck and Government responsibility to provide job were not considered by most of the students as important variables to determine their future earnings. Both these variables show that most of students have internal locus of control regarding luck and government intervention for their future. $\mathrm{P}$ value also shows that there is significant effect of both these factors as they are highly significant for entrepreneurial intentions. One question of "external connections" though is not significant and challenges the following two questions results, but still we can say that entrepreneurial intentions are function of internal locus of control.

Table-2 Impact of Self-Efficacy and Locus of Control on Entrepreneurial Intentions

\begin{tabular}{|c|c|c|c|c|}
\hline & & \multicolumn{2}{|c|}{ Total } & \multirow{2}{*}{$\begin{array}{c}p \\
\text { value }\end{array}$} \\
\hline & & $\mathbf{N}$ & $\%$ & \\
\hline \multicolumn{5}{|l|}{ Self Efficacy } \\
\hline \multirow{2}{*}{$\begin{array}{l}\text { Knowing me, I will definitely find a job when I } \\
\text { complete my university degree }\end{array}$} & TRUE & 155 & 57 & \multirow{2}{*}{0.01} \\
\hline & Not Sure & 108 & 31 & \\
\hline
\end{tabular}




\begin{tabular}{|lcccc|} 
& FALSE & 33 & 12 & \\
\hline If I work hard and get good grade, I will get a job & TRUE & 148 & 54 & \\
when complete university studies & Not Sure & 67 & 24 & 0.009 \\
& FALSE & 61 & 22 & \\
\hline Locus of Control & & & & \\
& TRUE & 112 & 40 & \\
Connection with people will help me find a job when I & Not Sure & 90 & 33 & 0.068 \\
complete my university qualification & FALSE & 74 & 27 & \\
& TRUE & 95 & 34 & \\
I need to be Lucky to find a job when I complete my & Not Sure & 45 & 17 & 0.02 \\
university degree & FALSE & 136 & 49 & \\
\hline & TRUE & 91 & 33 & \\
\hline The Government has to provide me with a job when I & Not Sure & 52 & 19 & 0.02 \\
complete my degree & FALSE & 133 & 48 & \\
& & & &
\end{tabular}

\section{Conclusion}

Various studies have been conducted to see impact of different variables on entrepreneurial intentions of students. In this study few of those variables have been used to see their collective results and impact on entrepreneurial intentions of students. Our studies prove that students, irrespective of gender, have almost equal inclination towards entrepreneurial attitude. But past experience, parental/family exposure to business and educational impact is significant on the future intentions to become an entrepreneur.

This study also proves that students with internal locus of control are more likely to become entrepreneur in future and they show great attitude towards entrepreneurial inclination. But the elements of locus of control have shown different results; one element of locus of control is totally insignificant with entrepreneurial intentions but two other elements have shown highly significant results. Overall we can say that personality traits can depict future intentions among students to become an entrepreneur. 


\section{References}

Adejimola A. S., Olufunmilayo T. O. (2009) 'Spinning off an entrepreneurship culture among Nigerian university students: prospects and challenges', African Journal of Business Management, Vol. 3, pp. 80-88.

Bonnett, C. Furnham, A. (1991), 'Who wants to be an entrepreneur? A study of adolescents interested in a young enterprise scheme', Journal of Economic Psychology, Vol. 12(3), pp. 465-478.

Boynd. N. G., \& Vozikis G. S. (1994) 'The influence of self efficacy and development of entrepreneurial intentions and actions', Entrepreneurial theory and practice, Vol. 18, pp. 63-90.

Carr. J.C., \& Sequeira J.M. (2006) 'Prior family business exposure as intergenerational influence and entrepreneurial intent: A theory of planned behavior approach', Journal of Business Research, Vol. 60, pp. 1090-1098.

Chen, C.C., Greene, P. G. \& Crick. A. (1998) 'Does Entrepreneurial Self Efficacy distinguish Entrepreneurs from Managers', Journal of Business Venturing, Vol. 13, pp. 295-316.

Cromie, S. (2000) 'Assessing entrepreneurial inclination: Some approaches and empirical evidence', European Journal of Work and Organizational Psychology, Vol. 9(1), pp. 7-30.

Gartner, W. (1988) 'Who is an entrepreneur? Is the wrong question', American Journal of Small Business, Vol. 12, pp. 11-32.

Ho, T.S. and Koh, H.C. (1992) 'Differences in psychological characteristics between entrepreneurially inclined and non-entrepreneurially inclined accounting graduates in Singapore', Entrepreneurship, Innovation and Change: An International Journal, 1, pp. 43-54.

Ismail M., Khalid S. A., Othman M., Jusoff H. K., Rahman N. A., Kassim K. M. and Zain R. S. (2009) 'Entrepreneurial intentions among Malaysian students', International Journal of Business and Management, Vol. 4(10), pp. 54-60.

Koh, H.C. (1996) 'Testing hypotheses of entrepreneurial characteristics: A study of Hong Kong MBA students', Journal of Managerial Psychology, Vol. 11(3), pp. 12-25.

Kolvereid, L. (1996). 'Prediction of employment status choice intention', Entrepreneurship Theory and Practice, Vol. 21(1), pp. 47-57.

Krueger, N.F. (1993) 'The impact of prior entrepreneurial exposure on perceptions of new venture desirability and feasibility' Entrepreneurship Theory and Practice, Vol. 18(1), pp. 5-21.

Mazzarol, T., Volery, T., Doss, N. \& Thein, V. (1999) 'Factors influencing small business star-ups', International Journal of Entrepreneurial Behavior and Research, Vol. 5(2), pp. 48-63.

McGee J.E., Peterson, M., Mueller S. L. \& Sequeira. J. M. (2009) 'Entrepreneurial Self Efficacy: Refining the Measure', Entrepreneurial theory and practice, Baylor University.

Pervin, L.A. (1980) Personality: Theory, Assessment and Research, John Wiley \& Sons, New York, NY.

Robinson, P.B., Huefner, J.C., Hunt, H.K. (1991), 'Entrepreneurial research on student subjects does not generalize to real world entrepreneurs', Journal of Small Business Management, Vol. 29, pp. 42-50.

Rotter, J.B. (1966) 'Generalized expectancies for internal versus external control of reinforcement', Psychological Monographs: General and Applied, Vol. 80(1), pp. 609-619.

Shaver, K.G. and Scott, L.R. (1991) 'Person, process, choice: the psychology of new venture creation', Entrepreneurship Theory and Practice, Vol. 16(2), pp. 23-31.

Spector, P.E. (1988) 'Development of the work locus of control scale', Academy of Management Review, Vol. 4, pp. 361-384. 
Wood. R., and Bandura. A. (1986) 'Social cognitive theory of organizational management', Journal of Occupational Psychology, Vol. 61, p. 335-340.

Yosuf M., Sandu M. S., \& Jain K. K. (2007) 'Relationship between psychological characteristics and entrepreneurial inclination: A case study of students at university Tun Abdul Razak', Journal of Asia Entrepreneurship and sustainability, Vol. 3(2), pp. 12-19. 